\title{
Correction: Systematic review of innovation design contests for health: spurring innovation and mass engagement
}

Pan SW, Stein G, Bayus B, et al. Systematic review of innovation design contests for health: spurring innovation and mass engagement. BMJ Innov 2017;3:227-37.

The funding statement for this article should read: This study was supported by the US National Institutes of Allergy and Infectious Diseases (NIAD1R01AI114310) and Fogarty International Center (R25TW009340).

(c) Article author(s) (or their employer(s) unless otherwise stated in the text of the article) 2018. All rights reserved. No commercial use is permitted unless otherwise expressly granted.

BMJ Innov 2018;4:4. doi:10.1136/bmjinnov-2017-000203corr1

D) Check for updates 